\title{
PENGARUH SELF-ESTEEM DAN KECERDASAN EMOSI TERHADAP PERILAKU PROSOSIAL
}

\author{
Nuris Fakhma Hanana \\ Fakultas Psikologi UIN Syarif Hidayatullah Jakarta
}

\begin{abstract}
The study aimed to examine the effect of self-esteem, emotional intelligence, gender, and age on prosocial behavior at Daarul Rahman Islamic Boarding School in Jakarta. The sample in this study amounted to 200 students taken by using probability sampling techniques. The instruments in this study are adaptations of the prosocial behavior scale and self-esteem, namely, Prosocial Tendencies Measurement and The School Short-form Coopersmith Self-esteem Inventory. Furthermore, the scale of emotional intelligence is developed by researchers based on aspects of emotional intelligence from Goleman (1998). The results showed that the variables of self-esteem, emotional intelligence, gender, and age are significantly affected prosocial behavior with a contribution of $35.5 \%$. Out of the eleven variables studied, there are four dimensions that have a significant effect on prosocial behavior, namely aspirations, recognizing one's own emotions, social skills and gender
\end{abstract}

Keywords: Prosocial behavior, self-esteem, emotional intelligence

\begin{abstract}
Abstrak
Penelitian ini bertujuan untuk menguji pengaruh self-esteem, kecerdasan emosi, serta jenis kelamin dan usia terhadap perilaku prososial di Pondok Pesantren Daarul Rahman Jakarta. Sampel dalam penelitian ini berjumlah 200 santri diambil dengan menggunakan teknik probability sampling. Instrumen dalam penelitian ini merupakan adaptasi dari skala perilaku prososial dan self-esteem, yaitu Prosocial Tendencies Measurement dan The School Short-form Coopersmith Self-esteem Inventory. Sedangkan skala pada kecerdasan emosi dikembangkan sendiri oleh peneliti berdasarkan aspek-aspek kecerdasan emosi dari Goleman (1998). Hasil penelitian menunjukkan bahwa variabel self-esteem, kecerdasan emosi, jenis kelamin, dan usia secara signifikan memengaruhi perilaku prososial dengan kontribusi sebesar 35.5\%. Dari sebelas variabel yang diteliti, ada empat dimensi yang berpengaruh signifikan terhadap perilaku prososial, yaitu aspirations, mengenali emosi sendiri, keterampilan sosial dan jenis kelamin.
\end{abstract}

Kata kunci: Perilaku prososial, self-esteem, kecerdasan emosi. 


\section{PENDAHULUAN}

Manusia diciptakan oleh Allah SWT dimuka bumi ini sebagai makhluk sosial. Artinya, manusia tidak dapat untuk hidup sendiri karena sebagian besar dari aktivitas dalam kehidupannya melibatkan interaksi dengan orang lain. Oleh karena itu, agar tercipta interaksi yang baik, beberapa dari tindakan manusia cenderung mengarah kepada kepentingan masyarakat (bersama), seperti membantu, menolong berderma dan lainnya (Walgito, 2008). Perilaku tersebut dinamakan sebagai perilaku prososial dalam psikologi.

Perilaku prososial menurut Eisenberg (1989) adalah tindakan sukarela yang dimaksudkan untuk memberikan keuntungan pada individu atau sekelompok individu. Perilaku prososial ini meliputi aspek seperti menyumbang (donating), bekerjasama (cooperating), memberi (giving), menolong (helping), simpati (sympathy) dan altruism (Wispe dalam Zanden, 1984). Dalam Islam, aspek perilaku prososial salah satunya tercermin dalam himbauan: "Tolong-menolonglah kamu dalam kebajikan dan taqwa, dan janganlah kamu tolong menolong dalam perbuatan dosa" (QS. Almaidah: 2).

Walaupun begitu, sebuah penelitian mengemukakan bahwa budaya gotong royong dan tolong menolong, serta solidaritas sosial pada masyarakat sekarang ini cenderung menurun (Setiadi, dalam Hartati, 1997). Hal ini disebabkan karena banyaknya individu yang sibuk dan terpaku pada kepentingan pribadinya masing-masing sehingga kepedulian terhadap lingkungan kian menipis (Yusuf \& Listiara, 2012).

Menurunnya perilaku prososial, menurut Sabiq dan Djalali (2012) bukan hanya dirasakan di masyarakat umum, akan tetapi juga merambah ke dunia pesantren. Terlebih pada santri yang masuk ke dalam pusaran modernitas dan kehidupan hedonis. Lambat laun, etika yang dimiliki santri tersebut pudar. Dampaknya yaitu membuat perilaku prososial yang dimiliki santri menjadi menurun (Mun'im, dalam Sabiq \& Djalali, 2012).

Senada dengan pernyataan di atas, hasil wawancara peneliti kepada seorang ustadzah salah satu pesantren di Parung pada tanggal 12 November 2013, juga menyatakan bahwa kepedulian santri saat ini menurun drastis dari sebelumnya. Hal ini terlihat ketika terdapat santri yang sakit, santri lainnya cenderung tidak memberikan perhatian lebih seperti mengambilkan makanan atau sekadar menemaninya, melainkan hanya memantau kondisinya saja.

Menurunnya perilaku prososial di pesantren sebenarnya bisa diminimalisir, karena pesantren merupakan salah satu tempat untuk meningkatkan perilaku prososial pada remaja sebagai peserta didiknya. 
Santri dibiasakan hidup bersama-sama, yang mengharuskan mereka untuk saling berbagi dan peduli. Pembiasaan diri pada santri seperti itu tentunya akan membentuk mental kebersamaan, gotong royong, dan jiwa sosial (Asy'ari, 1996).

Kondisi menurunnya perilaku prososial dalam dunia pesantren memang bukan hanya tanggung jawab satu pihak tertentu saja, misalnya pembina santri, sebab ada banyak faktor yang memengaruhi tampil atau tidaknya perilaku prososial. Contohnya seperti kehadiran orang lain, kondisi lingkungan, dan desakan waktu (Taylor, Peplau \& Sears, 2009). Sedangkan menurut Eisenberg, Fabes, dan Spinrad (2006) faktor internal seperti asertif, emosi, religiusitas, self-esteem, dan norma-norma juga berpengaruh signifikan terhadap perilaku prososial.

Dari pernyataan di atas, menurut hemat penulis, jika santri di pondok sudah dibiasakan untuk memiliki sifat gotong royong dan bersosialisasi namun masih terdapat perilaku cuek, egois, dan tidak melakukan perilaku prososial, hal tersebut merupakan faktor dari santri itu sendiri. Alasan inilah yang mendorong peneliti lebih memfokuskan penelitian perilaku prososial pada faktor-faktor internal daripada faktor eksternal, terutama self-esteem, kecerdasan emosi, usia, dan jenis kelamin. Dengan pemaparan di atas, maka peneliti melakukan penelitian lebih mendalam dengan judul "Pengaruh self-esteem dan kecerdasan emosi terhadap perilaku prososial pada santri di Pondok Pesantren Daarul Rahman Jakarta."

\section{TEORI DAN HIPOTESIS}

\section{Perilaku prososial}

Eisenberg dan Mussen (1989) mendefinisikan perilaku prososial sebagai "voluntary actions that are intended to help or benefit another individual or group of individuals." Perilaku prososial merujuk pada suatu tindakan yang dilakukan secara sukarela untuk menolong atau memberikan manfaat bagi individu atau kelompok yang lain.

Merujuk pada Eisenberg dan Mussen (1989), Carlo dan Randall (2002) mengembangkan alat ukur perilaku prososial, yang kemudian digunakan dalam penelitian ini. Adapun masing-masing subskala perilaku prososial akan dijabarkan singkat sebagai berikut.

1. Altruisme

Perilaku prososial altruistic didefinisikan sebagai perilaku sukarela untuk menolong orang lain yang didasarkan motivasi utama berupa kebutuhan untuk menolong dan kepentingan untuk mensejahterakan orang lain dan selalu diikuti dengan respon simpati serta norma internal/ prinsip yang konsisten untuk menolong orang lain. 


\section{Compliant}

Perilaku prososial compliant didefinisikan sebagai permintaan menolong orang lain karena adanya permintaan verbal dan non-verbal. Perilaku prososial ini lebih sering dilakukan secara spontan.

3. Emotional

Perilaku prososial emotional adalah kecenderungan menolong orang lain atas dasar situasi emosional yang tinggi. Misalnya yaitu remaja yang tangannya terluka kemudian menangis dan mengeluarkan darah akan lebih menggugah emosi daripada mereka yang tangannya terluka tetapi tidak menunjukkan respon apapun. Faktor lain seperti hubungan kekerabatan juga mampu menggugah respon emosional orang yang mengamati.

4. Public

Perilaku prososial public didefinisikan sebagai perilaku yang dilakukan di depan orang lain yang dimotivasi dengan keinginan untuk mendapatkan penerimaan dan penghormatan.

5. Anonymous

Perilaku prososial anonymous didefinisikan sebagai tindakan menolong yang ditunjukan tanpa diketahui oleh orang yang telah diberikan pertolongan.

6. Dire

Perilaku prososial dire merupakan perilaku menolong yang ditunjukkan seseorang di antara situasi krisis atau keadaan darurat.

Dari ke-enam dimensi tersebut, semua akan ikut diteliti sebagai dimensi variabel perilaku prososial.

\section{Self-esteem}

Self-esteem menurut Coopersmith (1990) adalah suatu evaluasi yang dibentuk berdasarkan kebiasaan individu memandang dirinya terutama mengenai sikap menerima atau menolak dan indikasi besarnya kepercayaan individu terhadap kemampuannya, keberartiannya, kesuksesannya, dan keberhargaannya. Secara singkat self-esteem adalah "personal judgment" mengenai perasaan berharga atau berarti yang diekspresikan dalam sikapsikap individu terhadap dirinya.

Coopersmith (1990) menyebutkan bahwa self-esteem terdiri dari empat dimensi yaitu Successes, values, aspirations, defenses, yang masingmasing akan dijabarkan sebagai berikut.

a. Keberhasilan (Successes)

Successes atau keberhasilan adalah tingkat pencapaian yang tinggi dengan tingkatan dan tugas yang bervariasi untuk setiap individu. Pemaknaan yang berbeda-beda terhadap keberhasilan ini disebabkan oleh faktor individu dalam memandang kesuksesan dirinya dan juga dipengaruhi oleh kondisi-kondisi budaya yang memberikan nilai pada bentuk-bentuk tertentu dari kesuksesan. 
Dalam situasi sosial tertentu, seorang individu mungkin lebih memaknakan keberhasilan dalam bentuk kekayaaan, kekuasaan, penghormatan, independen, dan kemandirian. Terdapat empat tipe pengalaman berbeda yang mendefinisikan tentang keberhasilan. Setiap hal tersebut memberikan kriteria untuk mendefinisikan keberhasilan itu adalah area power, area significance, area competence dan area virtue.

b. Nilai-nilai (values)

Setiap individu berbeda dalam memberikan pemaknaan terhadap keberhasilan yang ingin dicapai dalam beberapa area pengalaman. Perbedaan-perbedaan ini merupakan fungsi dari nilai-nilai yang diinternalisasikan dari orang tua dan figur-figur signifikan lainnya dalam hidup. Faktor-faktor seperti penerimaan (acceptance) dan respek dari orang tua merupakan sesuatu yang dapat memperkuat penerimaan nilai-nilai dari orang tua tersebut. Hal ini juga mengungkapkan bahwa kondisi-kondisi yang mempengaruhi pembentukan self-esteem akan berpengaruh pula dalam pembentukan nilai-nilai yang realistis dan stabil.

c. Aspirasi-aspirasi (Aspirations)

Menurut Coopersmith (1990), penilaian diri (self judgement) meliputi perbandingan antara performance dan kapasitas aktual dengan aspirasi dan standar personalnya. Jika standar tersebut tercapai, khususnya dalam area tingkah laku yang bernilai, maka individu akan menyimpulkan bahwa dirinya adalah orang yang berharga. Ada perbedaan esensial antara tujuan yang terikat secara sosial (public goals) dan tujuan yang bersifat self significant yang ditetapkan individu. Individu-individu yang berbeda tingkat self-esteemnya tidak akan berbeda dalam public goalnya, tetapi berbeda dalam personal ideals yang ditetapkan untuk dirinya sendiri. Individu dengan selfesteem tinggi menentukan tujuan yang lebih tinggi dibandingkan dengan individu dengan self-esteem yang lebih rendah.

d. Pertahanan (defenses)

Defenses adalah kemampuan untuk mengeliminir stimulus yang mencemaskan, menjaga ketenangan, serta mengevaluasi diri dan tingkah laku secara efektif. Menurut Coopersmith (1990), beberapa pengalaman dapat merupakan sumber evaluasi diri yang positif, namun ada pula yang menghasilkan penilaian diri yang negatif. Kenyataan ini tidak akan mudah diamati dan diukur pada tipe individu sebagaimana pengamalan merupakan bahan mentah yang digunakan dalam membuat penilaian dan interpretasi tiap individu terhadapnya tidaklah senantiasa seragam. Interpretasi akan bervariasi sesuai dengan karakteristik individu dalam mengatasi distress dan situasi ambigu serta dengan tujuan dan harapanharapannya. 


\section{Kecerdasan emosi}

Kecerdasan emosi menurut Goleman (1998) adalah kemampuan mengenali perasaan diri sendiri dan perasaan orang lain, kemampuan memotivasi diri sendiri, serta kemampuan mengelola emosi dengan baik pada diri sendiri dan dalam hubungannya dengan orang lain.

Menurut Goleman (1998) kecerdasan emosi terdiri dari lima dimensi, yaitu mengenali emosi diri, mengelola emosi, memotivasi diri, mengenali emosi orang lain dan keterampilan sosial.

a. Mengenali emosi diri (self awareness)

Mengenali emosi diri berarti mengetahui apa yang kita rasakan pada suatu saat dan menggunakannya untuk memandu pengambilan keputusan diri sendiri, memiliki tolak ukur yang realistis atas kemampuan diri dan kepercayaan diri yang kuat. Kemampuan ini berupa kesadaran diri (self awarenees) dalam mengenal perasaan sewaktu perasaan itu terjadi. Pada tahap ini diperlukan adanya pemantauan perasaan dari waktu ke waktu agar timbul wawasan psikologis dan pemahaman tentang diri. Ketidakmampuan untuk mencermati perasaan yang sesungguhnya membuat diri berada dalam kekuasaan perasaan. Oleh karenanya tidak peka akan perasaan yang sesungguhnya akan berakibat buruk bagi pengambilan keputusan suatu masalah. Kemampuan kesadaran diri ini adalah kemampuan dalam menangani emosi diri sendiri dan pengaruhnya, serta mengetahui kekuatan dan kelemahan diri sendiri.

b. Mengelola emosi (selfmanagement)

Mengelola emosi adalah kemampuan untuk menangani, mengekspresikan, dan mengendalikan emosi serta memiliki kepekaan terhadap kata hati untuk digunakan dalam hubungan dan tindakan sehari-hari. Mengelola emosi merupakan kemampuan individu dalam menangani perasaan agar dapat terungkap dengan tepat sehingga tercapai keseimbangan dalam dirinya. Selain itu juga terdapat kemampuan kontrol diri yang bertujuan menjaga keseimbangan emosi dan bukan menekannya, karena setiap perasaan memiliki nilai dan makna. Kemampuan dalam menampilkan emosi yang wajar, selaras antara perasaan dan lingkungan.

c. Memotivasi diri (motivating oneself)

Motivasi diri adalah kemampuan menggunakan hasrat untuk setiap saat membangkitkan semangat dan tenaga dalam mencapai keadaan yang lebih baik, kemampuan mengambil inisiatif dan bertindak secara efektif, serta kemampuan bertahan dalam menghadapi kegagalan dan frustasi.

d. Mengenali emosi orang lain (emphaty) 
Empati merupakan kemampuan merasakan apa yang dirasakan oleh orang lain, memahami perspektif orang lain, menimbulkan hubungan saling percaya serta menyelaraskan diri dengan berbagai tipe individu. Kunci dalam memahami perasaan atau emosi orang lain adalah kemampuan untuk membaca pesan nonverbal (misalnya gerak-gerik, ekspresi wajah). Merasakan yang dirasakan oleh orang lain, mampu memahami persepektif mereka, menumbuhkan hubungan saling percaya dan menyelaraskan diri dengan bermacam-macam orang.

e. Keterampilan Sosial (social skills)

Seni dalam membina hubungan dengan orang lain merupakan keterampilan sosial (social skills) yang mendukung keberhasilan dalam pergaulan dengan orang lain. Tanpa memiliki keterampilan tersebut seorang individu akan mengalami kesulitan dalam bergaul dengan orang lain. Menangani emosi dengan baik ketika berhubungan dengan orang lain dan dengan cermat membaca situasi dan jaringan sosial, berinteraksi dengan lancar menggunakan keterampilan-keterampilan ini untuk memengaruhi dan memimpin, bermusyawarah dan menyelesaikan perselisihan dan untuk bekerja dalam team.

Ada pengaruh yang signifikan dari selfesteem (successes, values, aspirations dan defenses), kecerdasan emosi (kesadaran diri, mengelola emosi, motivasi diri, mengenal emosi orang lain dan keterampilan sosial), serta variabel demografis jenis kelamin dan usia terhadap perilaku prososial.

\section{Hipotesis minor:}

$\mathrm{Ha}_{1} \quad$ : Ada pengaruh yang signifikan dimensi successes pada variabel selfesteem terhadap perilaku prososial.

$\mathrm{Ha}_{2} \quad$ : Ada pengaruh yang signifikan dimensi values pada variabel selfesteem terhadap perilaku prososial.

$\mathrm{Ha}_{3} \quad$ : Ada pengaruh yang signifikan dimensi aspirations pada variabel selfesteem terhadap perilaku prososial.

$\mathrm{Ha}_{4} \quad$ : Ada pengaruh yang signifikan dimensi defenses pada variabel selfesteem terhadap perilaku prososial.

$\mathrm{Ha}_{5}$ : Ada pengaruh yang signifikan dimensi kesadaran diri pada variable kecerdasan emosi terhadap perilaku prososial.

$\mathrm{Ha}_{6} \quad$ : Ada pengaruh yang signifikan dimensi mengelola emosi pada variabel kecerdasan emosi terhadap perilaku prososial.

$\mathrm{Ha}_{7} \quad$ : Ada pengaruh yang signifikan dimensi motivasi diri pada variabel kecerdasan emosi terhadap perilaku prososial.

$\mathrm{Ha}_{8} \quad$ : Ada pengaruh yang signifikan dimensi mengenal emosi orang lain pada variabel kecerdasan emosi terhadap perilaku prososial. 
$\mathrm{Ha}_{9} \quad$ : Ada pengaruh yang signifikan dimensi keterampilan sosial pada variabel kecerdasan emosi terhadap perilaku prososial.

$\mathrm{Ha}_{10}$ : Ada pengaruh yang signifikan variabel demografis jenis kelamin terhadap perilaku prososial.

$\mathrm{Ha}_{11}$ : Ada pengaruh yang signifikan variabel demografis usia terhadap perilaku prososial.

\section{METODE PENELITIAN}

\section{Populasi, sampel dan teknik pengambilan sampel}

Populasi dalam penelitian ini adalah santri Pondok Pesantren Daarul Rahman Jakarta, kelas I, II, III, IV, dan V, tahun ajaran 2013-2014. Santri kelas VI tidak diikutkan dalam penelitian ini karena sedang fokus mengikuti ujian akhir pondok. Oleh karena itu, jumlah total populasi santri dalam penelitian ialah sebanyak 503 santri. Mereka terdiri atas 270 santri kelas I, 65 santri kelas II, 50 santri kelas III, 60 santri kelas IV, dan 58 santri kelas V. Selanjutnya, dari jumlah populasi tersebut peneliti menetapkan sampel sebanyak 200 santri atau 40 persen dari populasi. Penetapan jumlah sampel tersebut disesuaikan dengan peneliti berdasarkan pertimbangan waktu dan dana dalam penelitian ini.

Pengambilan sampel pada penelitian ini menggunakan teknik probability sampling melalui cara stratified random sampling, dimana masingmasing populasi memiliki peluang yang sama untuk ditetapkan menjadi sampel.

\section{HASIL PENELITIAN}

Uji hipotesis untuk mengetahui pengaruh masing-masing IV terhadap DV dalam penelitian ini dilakukan analisis dengan teknik multiple regresion. Adapun hasil pengujian tersebut adalah sebagai berikut:

\section{Tabel 1}

\section{Model Summary Analisis Regresi}

\begin{tabular}{|c|c|c|c|c|c|}
\hline \multirow[b]{2}{*}{ Model } & & \multirow[b]{2}{*}{$\mathrm{R}$} & & \multicolumn{2}{|c|}{ Model Summary } \\
\hline & & & $\begin{array}{c}\mathrm{R} \\
\text { Square }\end{array}$ & $\begin{array}{c}\text { Adjusted R } \\
\text { Square }\end{array}$ & $\begin{array}{l}\text { Std. Error of the } \\
\text { Estimate }\end{array}$ \\
\hline $\begin{array}{l}\text { dimens } \\
\text { ion0 }\end{array}$ & 1 & $.596^{\mathrm{a}}$ & .355 & .317 & 7.60103 \\
\hline
\end{tabular}


Selanjutnya peneliti melihat variabel yang memiliki pengaruh terhadap perilaku prososial. dengan melihat koefisien regresi tiap independent variable. Jika nilai $\mathrm{t}>1,96$ maka koefisien regresi tersebut signifikan Hal ini menunjukkan bahwa bahwa IV tersebut memiliki dampak yang signifikan terhadap perilaku prososial

\section{Tabel 2}

Koefisien regresi

\begin{tabular}{|c|c|c|c|c|c|}
\hline \multirow[b]{2}{*}{ Model } & \multicolumn{2}{|c|}{$\begin{array}{l}\text { Unstandardize } \\
\text { d Coefficients }\end{array}$} & \multirow{2}{*}{$\begin{array}{l}\text { Standardiz } \\
\text { ed } \\
\text { Coefficients } \\
\text { Beta }\end{array}$} & \multirow[t]{2}{*}{$\mathrm{T}$} & \multirow[t]{2}{*}{ Sig } \\
\hline & B & $\begin{array}{l}\text { Std. } \\
\text { Erro } \\
\mathrm{r}\end{array}$ & & & \\
\hline 1 (Constant) & 1.097 & 7.361 & & .149 & .882 \\
\hline Successes & -.053 & .087 & -.047 & -.606 & .545 \\
\hline Values & -.047 & .086 & .038 & .553 & .581 \\
\hline Aspirations & .269 & .082 & .242 & 3.279 & .001 \\
\hline Defences & -.006 & .076 & -.006 & -.077 & .939 \\
\hline $\begin{array}{l}\text { Mengenali } \\
\text { emosi sendiri }\end{array}$ & .229 & .114 & .175 & 2.005 & .046 \\
\hline $\begin{array}{l}\text { Mengelola } \\
\text { emosi }\end{array}$ & .080 & .091 & .066 & .873 & .384 \\
\hline Memotivasi diri & .071 & .074 & .071 & .958 & .340 \\
\hline $\begin{array}{l}\text { Mengenali } \\
\text { emosi orang lain }\end{array}$ & -.034 & .083 & -.029 & -.411 & .682 \\
\hline $\begin{array}{l}\text { Keterampilan } \\
\text { social }\end{array}$ & .237 & .088 & .213 & 2.702 & .008 \\
\hline Usia & .227 & .329 & .041 & .691 & .491 \\
\hline Jenis kelamin & 2.525 & 1.168 & .136 & 2.161 & .032 \\
\hline
\end{tabular}

a. Depent variabel: perilaku prososial

Hal ini berarti bahwa dari sebelas independent variable hanya empat yang signifikan yaitu aspirations, mengenali emosi sendiri, keterampilan sosial dan jenis kelamin.

\section{KESIMPULAN DAN SARAN}

\section{Kesimpulan}

Berdasarkan hasil analisis data penelitian maka kesimpulan yang dapat diambil dari penelitian ini adalah ada pengaruh yang signifikan dari self-esteem (successes, values, aspirations dan defenses), kecerdasan emosi 
(mengenali emosi sendiri, mengelola emosi, memotivasi diri, mengenali emosi orang lain, keterampilan sosial) serta variabel demografis usia dan jenis kelamin terhadap perilaku prososial pada santri Pondok Pesantren Daarul Rahman Jakarta.

Kemudian berdasarkan hasil uji hipotesis yang menguji signifikansi masing-masing koefisien regresi terhadap dependent variable, hanya terdapat empat koefisien regresi yang secara signifikan memengaruhi perilaku prososial, yaitu dimensi aspirations, mengenali emosi sendiri, keterampilan sosial, dan jenis kelamin.

\section{Diskusi}

Berdasarkan hasil penelitian dan pengujian hipotesis, diketahui bahwa ada pengaruh yang signifikan dari variabel self-esteem (aspirations), kecerdasan emosi (keterampilan sosial) dan jenis kelamin terhadap perilaku prososial pada santri Pondok Pesantren Daarul Rahman Jakarta.

Meskipun dalam penelitian ini terbukti bahwa variabel self-esteem dan kecerdasan emosi berpengaruh secara signifikan terhadap perilaku prososial, namun dimensi-dimensi yang berpengaruh terhadap perilaku prososial hanya aspirations, mengenali emosi sendiri, keterampilan sosial dan jenis kelamin. Sedangkan dimensi lainnya tidak berpengaruh terhadap perilaku prososial.

Dalam penelitian ini dimensi aspirations pada variabel self-esteem terbukti berpengaruh terhadap perilaku prososial. Hal tersebut bisa disebabkan karena rata-rata santri memiliki nilai kategorisasi aspirations yang tinggi. Aspirations berkaitan kuat dengan harapan dan tujuan seseorang. Keduanya merupakan salah satu faktor pendorong seseorang untuk melakukan perilaku prososial (Staub, 2003). Harapan dan tujuan seseorang dalam melakukan perilaku prososial menurutnya pula, seperti misalnya, meningkatkan derajat, mengurangi peperangan, berhubungan baik dengan orang lain, dan persahabatan.

Pengaruh yang signifikan pada aspirations dalam penelitian ini bisa dikaitkan dengan persahabatan termasuk harapan untuk diterima dalam kelompok. Hal ini sesuai dengan pernyataan Sarwono (2009) yang menyatakan bahwa kebutuhan akan persetujuan (need of approval) akan mendorong seseorang untuk melakukan perilaku prososial. Diterima oleh teman sebaya memang sangat penting bagi remaja, karena mereka lebih sering untuk meluangkan waktu dengan teman-temannya (Santrock, 1995). Penelitian Twenge, Ciarocco, Bartels, Baumester dan De Wall (2007) juga membuktikan bahwa orang yang diterima oleh teman sebaya akan lebih mudah menolong daripada orang yang ditolak dalam kelompok.

Pada kecerdasan emosi, dimensi yang berpengaruh adalah mengenali emosi sendiri. Hasil yang didapat memang tidak sejalan dengan penelitian yang dilakukan oleh Farikha (2011). Karena dalam penelitiannya tidak menemukan adanya pengaruh antara mengenali emosi 
sendiri terhadap perilaku prososial. Namun, pernyataan White dan Gerstain (dalam Sarwono, 2009) menyebutkan bahwa self monitoring berpengaruh terhadap perilaku prososial. Kemampuan memantau diri (self monitor) berarti adalah mengetahui apa kelebihan, kekurangannya dan mampu menghadapi dan mengatasi permasalahan yang ada. Pada santri yang terbiasa hidup sendiri, dan hidup mandiri, bisa saja memacu mereka untuk mampu mengenal dirinya dan kemampuannya dengan lebih baik. Hal tersebut juga dibuktikan dengan kategorisasi mengenali emosi sendiri pada subjek dalam penelitian ini termasuk tinggi.

Selain mengenali emosi sendiri, dimensi keterampilan sosial dalam penelitian ini juga berpengaruh terhadap perilaku prososial. Meskipun kategorisasi keterampilan sosial pada penelitian ini cenderung rendah, namun intensitas kebersamaan santri di Pondok, membentuk santri untuk mampu bersosialisasi dengan baik. Hal tersebut, akan membantu mereka untuk bertingkah laku yang sesuai dan positif, supportive, serta sedikit memiliki konflik dengan teman-temannya dan hasilnya akan meningkatkan perilaku prososial (Eisenberg dkk, 2006).

Variabel selanjutnya yang berpengaruh terhadap perilaku prososial adalah variabel jenis kelamin (gender). Variabel ini berpengaruh terhadap perilaku prososial sebesar $1.8 \%$. Hasil penelitian tidak sesuai dengan penelitian Afolabi (2013) yang menyatakan tidak ada hubungan antara jenis kelamin dengan perilaku prososial, namun hasil tersebut sesuai dengan pernyataan Bierhoff (2002) serta penelitian Caprara dan Steca (2005) yang menyatakan bahwa jenis kelamin berpengaruh terhadap perilaku prososial. Namun hasilnya kontradiktif, karena temuan sebelumnya menyatakan bahwa perempuan lebih prososial daripada laki-laki. Sedangkan dalam penelitian ini laki-laki menjadi dominan dalam penelitian, dengan hasil yang signifikan. Hal tersebut bisa saja terjadi karena pada laki-laki, mereka akan tampil menolong secara langsung, saat terjadi sesuatu. Bisa dikatakan seperti pahlawan (Eagly \& Crowley dalam Afolabi, 2013). Hasil ini terkait dengan peran tradisional laki-laki yang dipandang lebih kuat dan lebih memiliki keterampilan untuk melindungi diri. Sementara sifat perempuan, lebih tampil menolong pada situasi yang bersifat memberi dukungan emosi, merawat, dan mengasuh (Daux, Dane \& Wrightsman, dalam Sarwono, 2009).

Pada variabel self-esteem dan kecerdasan emosi terdapat tujuh variabel yang tidak berpengaruh terhadap perilaku prososial yaitu, successes, values, defenses, mengelola emosi, mengenali emosi orang lain, memotivasi diri dan usia. Ada beberapa faktor yang menyebabkan beberapa dimensi tersebut tidak berpengaruh terhadap perilaku prososial.

Faktor pertama, jika dilihat dari data, beberapa dimensi tersebut yang tidak signifikan tersebut memiliki kategorisasi rata-ratanya rendah. $\mathrm{Hal}$ tersebut terbukti pada dimensi defenses, rata-rata santri memiliki kategorisasi rendah, yaitu sejumlah 119 dan hanya 91 santri yang memiliki 
defensesyang tinggi. Begitu juga pada dimensi mengenali emosi orang lain, dimana hanya 88 santri nilai kategorisasi mengenali emosi orang lain yang tinggi. Selain itu subjek dalam penelitian ini berada pada fase remaja. Pada masa tersebut, seseorang mengalami banyak perubahan, diantaranya perubahan fisik, dan kelenjar. Inilah yang membuat emosinya sering meledak dan terkadang melampiaskan emosi dengan marah dan dalam istilah sering disebut dengan periode badai dan tekanan (Hurlock, 1996). Inilah yang membuat mereka kurang bersikap alruistik.

Apabila dikaitkan dengan teori psikososial Erikson, usia remaja berada berada fase identitas versus kebingungan identitas (identity versus identity confusion). Pada saat itu fokus utama remaja adalah pencarian identitas (Santrock, 2011). Hal tersebut membuat sikap dan prilaku mereka yang berubah-ubah untuk mencari minat, tujuan, serta harapan mereka yang sesuai di masa depan.

Adapun faktor lainnya, berasal dari kelemahan dan kekurangan peneliti dalam proses penelitian. Kekurangan tersebut disebabkan oleh tidak seimbangnya jumlah sampel antara lelaki dan perempuan, adanya bias budaya, bahasa dalam mengadaptasi item dari skala baku kurang tepat. Kelamahan lainnya menurut peneliti juga berasal dari santri pada saat mengisi kuesionare, seperti adanya faking good terhadap item karena kecenderungan subjek untuk mengisi sesuai dengan norma yang berlaku, serta mood subjek pada saat pengisian kuesionare. Hal tersebut mampu mempengaruhi tidak signifikannya beberapa dimensi pada penelitian ini.

\section{Saran}

Pada penelitian ini, peneliti membagi saran menjadi dua, yaitu saran metodologi dan saran praktis. Saran metodologi berupa bahan pertimbangan untuk perkembangan penelitian selanjutnya, sementara saran praktis berupa bahan masukan bagi pembaca sehingga dapat mengambil manfaat dari penelitian ini.

\section{Saran Teoritis}

1. Pada penelitian ini, subjek yang digunakan hanya satu pondok, yaitu Pondok Pesantren Daarul Rahman. Saran bagi peneliti selanjutnya yaitu untuk tidak menggunakan subjek hanya dari satu pondok. Dengan demikian peneliti dapat mendapatkan wawasan yang lebih luas, seperti bagaimana perilaku prososial pada dua pesantren yang berbeda.

2. Kepada peneliti selanjutnya yang ingin mengkaji tentang perilaku prososial diharapkan untuk menambah variabel lain yang berpengaruh terhadap perilaku prososial, seperti variabel spritualitas, pola asuh, sef-concept, dan juga kepribadian. Hal tersebut berguna untuk memperkaya hasil penelitian dan pengetahuan tentang perilaku prososial. 


\section{Saran Praktis}

1. Saran bagi manajemen pondok adalah agar rutin mengadakan kebersamaan yang sistematis, seperti pelatihan pembentukan karakter Islami dan training motivasi atau kegiatan lainnya yang bertujuan mengarahkan santri dalam proses pembentukan karakter serta jati diri mereka. Hal tersebut terkait dengan hasil penelitian ini, yang membuktikan bahwa mengenali emosi sendiri dan aspiration memiliki pengaruh positif yang signifikan terhadap perilaku prososial.

2. Dalam penelitian ini ditemukan bahwa keterampilan sosial secara signifikan memengaruhi perilaku prososial. Berdasarkan hasil tersebut, peneliti sarankan agar pengurus pondok memperbanyak kegiatan yang mengasah kemampuan santri dalam bekerjasama, diantaranya seperti kegiatan pramuka, marawis, dan olahraga.

\section{DAFTAR PUSTAKA}

Afolabi, O. (2013) Roles of personality types, emotional intelligence and gender differences on prosocial behavior. Psychological thought. 6(1), 124-139. DOI: 10.5984

Asia, N. (2008) Hubungan antara harga diri dan asertivitas dengan perilaku prososial remaja. Skripsi. Surakarta. Fakultas Psikologi Universitas Muhammadiyah Surakarta.

Asy'ari, Z. (1996). Moralitas pendidikan pesantren.Yogyakarta. Lembaga Kajian Sumber Daya Manusia (LKPSM).

Bar-On, R. (2006). The Bar-on model of emotional intelligence (ESI). Psichotema.18, 13-25.

Baumeister, R. (2005). Rethinking self-esteem. Stanford Social Inovation review. $\quad$ Retrieved from http://www.academia.edu/8860170/Stanford_Social_Innovation_Re view 518 Memorial Rethinking Self-

Esteem Why nonprofits should stop_pushing selfesteem and start endorsing self-control

Baron, R.A., \& Byrne, D. (2005). Psikologi sosial.10 th ed. Jakarta: Erlangga.

Baron, R.A., Branscome, N., Byrne, D. (2008). Social psychology. $12^{\text {th }}$ ed. Pearson Education, Inc.

Bierhoff. (2002). Prosocial Behavior. New York. Psychology Press

Branden, N. (1992). The power of self esteem. Florida. Health Communication.inc

Carlo, G., \& Randall, B. A. (2002). The development of a measure of prosocial behaviors for late adolescents. Journal of Youth and Adolescence. 31(1), 31-44. 
Cherniss, C. (2000) Emotional Intelligence: What it is and why it matters, consortium for research on Emotional Intelligence in organizations.

Coopersmith, S., (1990) The Antecedents of self esteem, Consulting Psychologists Press

Deaux, K., Dane, F.C., Wrightman, L.S, \& Sigelman, C.K. (1990). Social psychology in the '90s. California: Pasific Grove.

Eisenberg, N. (2006). Social, emotional and personality development. $6^{\text {th }}$ ed. Hand book of child psychology.

Eisenberg, N., \& Mussen, P.H. (1989) The roots of prosocial behavior in children. Cambridge University Press. Cambridge.

Ervin, S. (2003). The psychology of good and evil. Cambrdige.

Fajri, N. (2013). Pengaruh self-esteem, kecerdasan emosi dan konformitas teman sebaya terhadap agresitifitas remaja.Skripsi. Jakarta: Fakultas Psikologi Universitas Islam Syarif Hidayatullah Jakarta.

Farikha, R. (2011) Pengaruh tipe kepribadian big five dan kecerdasan emosi terhadap perilaku prososial satuan polisi pamong praja kota tangerang.Skripsi. Jakarta: Fakultas Psikologi Universitas Islam Syarif Hidayatullah Jakarta.

Feldman, R.S. (1985). Social psychology: Theories, research and aplication. United States of America: McGraw-Hill Companies.

Goleman (1998). Working with Emotional Intelligence. New York. Bantam Dell.

Goleman, D. (1997). Kecerdasan emosional. Hermaya (terj). Jakarta: Gramedia Pustaka Utama.

Gregor, Gary, L, Conner Hubert, (1971) Reciptoral Altruisme: The effect of self-esteem and anticipation of face-to-face on reciprocation. Annual convention of the western psychological association, San Fransisco, California.

Hartaty, N. (1997). Perilaku dan motif prososial anak berbakat intelektual umum. Thesis. Fakultas Psikologi. Universitas Indonesia.

Heatherton, T ., Wyland, C . (2003). Assesing Self-esteem. Dartmouth Colege

Hills, P.R., Francis, L.J., \& Jennings, P., (2011), Reseived School Short From Coopersmith Self-Esteem Inventory. American Psychological Association, Retrieved from PsycTEST. DOI: 10.1037/t0565-000.

Hurlock, E. B. (1996). Psikologi perkembangan: Suatu pendekatan sepanjang rentang kehidupan. $5^{\text {th }}$. Jakarta: Erlangga.

Jannah, M. (2008). Hubungan antara kecerdasan ruhani dan tipe kepribadian ekstrovert terhadap perilaku prososial pada santri. Skripsi. Surakarta. Fakultas Psikologi Universitas Muhammadiyah Surakarta.

Mayer, Caruso, Gill, Salovey (2003). Measuring emotional intelligence with the MSCEIT V2.0. American Psychological Association. 3(1), 97-105. DOI: 10. 1037/1528-3542.3.1.97. 
Minchinton, (1993). Maximum self esteem: The hand book for reclaiming your sense of self worth. Kuala Lumpur. Golden books center Sdn, Bhd

Mruk, C.J. (2006). Self-Esteem research, theory and practice: Toward a positive psychology of self-esteem. $3^{\text {rd }}$ ed. New York: Springer Publishing Company. Inc

Nawawi, I., et, al. (2014). Syarah dan terjemah riyadhus shalihin. $10^{\text {th }}$ ed. Jakarta.Al-I;tishom.

Penner, L, A., Fritzsche, B, A., Craiger, J.P., Freifeld, T. R. (1995). Measuring the prosocial personality. Advances in personality assesment.10. Hillsdale, NJ: Erlbaum.

Pusa, V.(2010) Hubungan antara kecerdasan emosional dengan perilaku prososial pada karyawan area network PT Telkom Purwokerto. Skripsi. Semarang. Fakultas Psikologi Universitas Katolik Soegijapranata Semarang.

Rudyanto, E. (2010). Hubungan antara kecerdasan emosional dan kecerdasan spritual dengan perilaku prososial pada perawat. Skripsi. Surakarta: Fakultas Psikologi Universitas Sebelas Maret Surakarta.

Sabiq, Z.,\&Asad. D. (2012) Kecerdasan emosi, kecerdasan spiritual dan perilaku prososial santri pondok pesantren Nasyrul Ulum Pamekasan. Jurnal psikologi Indonesia.1(2), 53-65.

Salovey, P., \& Mayer (1990). Emotional intelligence. Baywood Publishing.

Santrock, J.W. (1995). Life Span development. Perkembangan Masa hidup, Achmad \& Juda (terj) Jakarta: Erlangga

Santrock, J.W. (2011). Masa perkembangan anak: Children. Pakpahan. V. Anugraheni, W (terj). Jakarta: Salemba.

Sarwono,S.W., \& Meinarno. (2009). Psikologi sosial. Jakarta: Salemba Humanika.

Sears, O. D. Freedman, J. L., \& Peplau, L. A . Social psychology. $5^{\text {th }}$. Michael Driyanto (terj). 1994. Jakarta : Erlangga.

Srimanjaya, D.(2007) Hubungan antara Orientasi Keagamaan dan Harga diri dengan Perilaku Prososial. Skripsi. Surakarta. Fakultas Psikologi Universitas Muhammadiyah Surakarta

Sweson,.R., \& Prelow, H. (2004) Ethnic identity, self esteem, and perceived efficacy as mediator of the relation of supportive parenting to psychosocial outcomes among urban adolescents. Jurnal of Adolescence (28), 465-477

Taufik. (2012). Empati: Pendekatan psikologi sosial. Jakarta: Rajawali Press

Twenge, J., Ciarocco., N., Bartels., Baumeister, R., \& De Wall, N. (2007). Social exlucion: decreas prosocial behavior. Jurnal of Personality and Social Psychology.92(1), 56-66.

Walgito, B. (2008). Psikologi sosial. Yogyakarta : Andi offset.

Wrightsman, S. L. (1977). Social psychology. California: Wadsworth Publishing Company, Inc. 
Yusuf, Z., \& Listiara, A. (2012). The difference between prosocial tendency regular classes and special classes SMAN 1 and SMAN 3 Semarang. Jurnal Psikologi. 1 (1), 120-138.

Zanden, V. J. W. (1993). Human development. $5^{\text {th }}$ ed. United Stated Of America ; Mc Graw-Hill,inc. 